\title{
DESAIN PENGUATAN KUALITAS POLITIK DINASTI DALAM PEMILIHAN KEPALA DAERAH
}

\section{THE DESIGN FOR STRENGTHENING THE QUALITY OF DYNASTIC POLITICS IN REGIONAL ELECTIONS}

\author{
Ahmad Siboy \\ Fakultas Hukum Universitas Islam Malang \\ Email: siboysalman@unisma.ac.id
}

\begin{abstract}
Abstrak
Tujuan penelitian ini untuk menguraikan faktor dan implikasi dari menjamurnya politik dinasti serta menemukan desain untuk membuat politik dinasti yang tidak bertentangan dengan semangat demokrasi lokal di Indonesia. Permasalahan penelitian ini adalah faktor dan implikasi yang membuat politik dinasti tumbuh subur dalam Pilkada serentak serta desain politik dinasti yang ideal. Metode penelitian yang digunakan yuridis normatif melalui pendekatan konsep, peraturan perundang-undangan, pendekatan kasus dan pendekatan sejarah. Hasil penelitian menunjukkan bahwa politik dinasti menjamur karena kepala daerah yang sedang menjabat sudah tidak dapat mencalonkan diri kembali, penguasa ditingkat nasional ingin memanfaatkan kekuasaanya untuk menempatkan anggota keluarganya sebagai penguasa ditingkat daerah. Akibatnya, banyak calon kepala daerah yang dicalonkan tanpa memiliki kompetensi dan kemauan untuk menjadi kepala daerah. Desain politik dinasti yang ideal dapat ditempuh dengan penguatan persyaratan untuk dinyatakan sah sebagai calon kepala daerah serta pengaturan yang dapat mencegah bakal calon kepala daerah yang tidak berkualitas dapat memenuhi persyaratan formal atau hukum sebagai calon kepala daerah.
\end{abstract}

\section{Kata Kunci: Desain, Politik Dinasti, Kepala Daerah}

\begin{abstract}
The purpose of this reseach is to describe the factors and implications of the proliferation of political dynasties and to find designs to create dynastic politics that do not conflict with the spirit of local democracy in Indonesia. The problem of this research is the factors and implications that make politics flourish in simultaneous Pilkada and the ideal dynastic political design. The research method used is normative juridical through the concept of an approach, legislation, case approach and historical approach. The results showed that dynastic politics mushroomed because the regional head as the ruler was unable to run again, the ruler at the national level wanted to use his power to place family members as rulers at the regional level. As a result, many candidates for regional heads are nominated without the competence and willingness to become regional heads. The ideal dynastic political design can be achieved with the requirements to be declared valid as a candidate for regional head as well as regulations that prevent unqualified regional head candidates from fulfilling formal or legal requirements as regional head candidates.
\end{abstract}


Keywords : Design, Dynastic Politics, Regional Heads

\section{A. Pendahuluan}

Pemilihan kepala daerah merupkan salah satu bagian dari sistem pengisian jabatan publik di Negara Kesatuan Republik Indonesia. Pada pemilihan kepala daerah terdapat pemilihan untuk pengisian jabatan Gubernur/Wakil Gubernur, Bupati/Wakil Bupati dan Wali Kota/Wakil Wali Kota. Setiap warga Negara yang ingin mengembangkan dirinya dalam pemerintahan maka dapat menggunakan jalur pemilihan kepala daerah (Pilkada) untuk mewujudkan keinginannya. Pilkada merupakan jalur legitimate untuk memperoleh mandat atau daulat rakyat. ${ }^{1}$

Setiap warga Negara memiliki hak untuk mencalonkan diri baik sebagai calon kepala daerah maupun sebagai calon wakil kepala daerah selama memenuhi ketentuan peraturan perundang-undangan. Salah satu persyaratan yang utama untuk maju sebagai calon kepala daerah dan wakil kepala daerah ialah berkaitan dengan

${ }^{1}$ Sodikin, Kedaulatan Rakyat dan Pemilihan Kepala Daerah Dalam Konteks UndangUndang Dasar Negara Republik Indonesia Tahun 1945, Jurnal Cita Hukum, Vol. II No. 1 Juni 2014. hlm. 106-107. tiket. Tiket dalam arti disini ialah tentang ambang batas dukungan untuk dapat menjadi peserta pemilihan.

Tiket atau ambang batas dukungan dapat diperoleh dari dua jalur, yakni, jalur partai politik dan jalur perseorangan. Jika ingin menempuh jalur partai politik maka pasangan bakal calon kepala daerah dan wakil kepala daerah baik tingkat Provinsi maupun tingkat Kabupaten/Kota maka harus mendapatkan dukungan partai politik atau gabungan partai politik yang memiliki minimal 20\% kursi DPRD (Dewan Perwakilan Rakyat Daerah). Bagi pasangan bakal calon kepala daerah dan wakil kepala daerah yang akan maju melalui jalur perseorangan maka harus mendapatkan dukungan berupa pengumpulan Kartu Tanda Penduduk (KTP-el) dari masyarakat. Peserta pemilihan yang maju melaui jalur partai politiik dan jalur perseorangan memiliki hak dan kewajiban yang sama.

Bersamaan dengan itu, tidak terdapat pembatasan bagi siapapun untuk maju sebagai peserta Pilkada selama haknya untuk dipilih dalam Pilkada tidak dicabut menurut ketentuan 
peraturan perundang-undangan atau vonis pengadilan bahkan seorang mantan narapidana dalam kasus serius crime sekalipun dapat menjadi calon kepala daerah. ${ }^{2}$ Artinya, yang terpenting dalam proses pencalonan seseorang sebagai peserta Pilkada bergantung kepada kemampuan dari setiap orang untuk memperoleh tiket atau melakukan komunikasi politik. Berkaitan dengan kondisi yang harus bergantung kepada tiket maka dua jalur (baik Parpol maupun perseorangan) akan dicoba oleh setiap orang yang ingin maju sebagai calon kepala daerah/wakil kepala daerah. Namun, diantara dua jalur tersebut, jalur partai politik merupakan jalur yang paling banyak diminati. Hal ini dapat dilihat dalam beberapa kali Pilkada khususnya dalam Pilkada terakhir tahun 2020 dimana hanya terdapat 70 calon dari jalur non partai politik dari 270 daerah yang menggelar Pilkada. ${ }^{3}$

\footnotetext{
${ }^{2}$ Nyoman Mas Aryani dan Bagus Hermanto, Justification of Political Rights of ExConvicted: Human Rights and Statutory Law Perspectives, Jurnal Konstitusi, Volume 17, Nomor 2, Juni 2020, hlm, 418-422.

${ }^{3}$ https://nasional.kompas.com/read/2020/09/ 01/17432151/70-bapaslon-penuhi-syaratsebagai-calon-perseorangan-pilkada-inirinciannya?page=all, diakses tanggal 13 November 2020, pukul 13.20 WIB
}

Jalur Parpol lebih diminati karena jalur ini lebih berkepastian dan membutuhkan waktu yang relatif lebih singkat ketimbang jalur perseorangan. Jika jalur perseorangan membutuhkan waktu pengumpulan KTP, verifikasi dan pernyataan dukungan serta lain-lain maka untuk jalur partai politik cukup meminta rekomendasi dari pengurus pusat partai politik yang memiliki kursi ditingkat DPRD.

Proses perolehan rekomendasi Parpol merupakan proses yang sangat dinamis dan tidak bisa dipetakan mengingat partai politik tidak memiliki pola yang pasti dalam penentuan siapa yang akan direkomendasikan sebagai calon kepala daerah dari Parpolnya. Seorang kader partai politik sekalipun tidak memiliki jaminan akan diusung oleh partainya untuk maju sebagai calon kepala daerah mengingat suatu partai politik lebih memilih untuk mengajukan pasangan calon lain ketimbang kadernya sendiri seperti dalam Pilkada Kabupaten Sumenep Tahun 2020, dimana Partai Hanura lebih memilih mendukung Pasangan Fattah Jasin-KH. Ali Fikri sebagai pasangan calona kepala daerah dan wakil kepala daerah ketimbang kadernya atau ketua DPC Hanura Kabupaten Sumenep (Nyai Eva) yang 
maju sebagai calon wakil Bupati berpasangan dengan Achmad Fauzi. ${ }^{4}$

Pola rekomendasi parpol yang tidak pasti dalam memberikan rekomendasi juga telah berimplikasi pada semakin suburnya politik dinasti. Politik dinasti dalam pemilihan kepala daerah ialah majunya anggota keluarga dari kepala daerah yang sedang menjabat atau keluarga dari penguasa sebagai calon kepala daerah atau wakil kepala daerah. Munculnya politik dinasti dalam Pilkada bukanlah merupakan fenomena baru dalam perebutan kekuasaan tingkat lokal atau perebutan posisi kepala daerah dan atau wakil kepala daerah. Politik dinasti telah terjadi sejak pemilihan kepala daerah masih belum digelar secara langsung atau tatkala kepala daerah masih dipilih oleh Dewan Perwakilan Rakyat Daerah (DPRD). Setelah Pilkada digelar secara langsung pun, politik dinasti merupakan fenomena yang tidak dapat dibendung. Satu sisi, politik dinasti merupakan hak asasi yang tidak bisa dilarang dalam sebuah pemilihan. Di sisi lain, politik dinasti cenderung bernuansa menguntungkan keluarga

\footnotetext{
${ }^{4}$ https://memorandum.co.id/dpp-hanurarekom-fattah-jasin-di-pilkada-sumenep-dpcmembantah/, diakses tanggal 20 November 2020, pukul 15.00 WIB
}

penguasa dan merugikan calon kepala daerah yang tidak memiliki trah keluarga pejabat.

\section{B. Metode Penelitian}

Penelitian tentang upaya penguatan kualitas politik dinasti dalam pemilihan kepala daerah serentak ini menggunkan jenis penilitian yuridis-normatif atau jenis penelitian doktrinal. Pendekatan yang digunakan adalah pendekatan konsep, pendekatan peraturan perundang-undangan, pendekatan kasus. Adapun sumber bahan hukum terdiri dari 3 sumber bahan hukum yang meliputi sumber bahan hukum primer, bahan hukum sekunder dan bahan hukum tersier. Bahan hukum tersebut kemudian dikumpulkan melalui cara inventarisasi dan klasifikasi untuk kemudian dianalisis secara deskriptif dan prekriftif.

\section{Pembahasan}

\section{Akar Politik dinasti}

Potret dinamika politik dinasti dalam Pilkada dapat terlihat dari calon kepala daerah dan/atau wakil kepala daerah yang masih memiliki hubungan keluarga dengan kepala daerah yang sedang menjabat atau penguasa lainnya baik ditingkat lokal maupun nasional. 
Dalam hal ini bisa istri, anak, menantu atau saudara kandung.

Politik dinasti terjadi karena beberapa faktor : pertama, politik dinasti terjadi karena kepala daerah yang sedang menjabat sudah tidak dapat mencalonkan kembali sebagai kepala daerah. Artinya, kepala daerah yang sedang menjabat tersebut sudah dua periode menjadi kepala daerah. Dalam konteks jabatan kepala daerah di Indonesia maka seseorang hanya dibolehkan menjabat untuk dua periode atau tidak dapat mencalonkan kembali untuk periode ketiga. Pembatasan periode jabatan inilah kemudian yang menyebabkan kepala daerah yang sedang berkuasa mencalonkan anggota keluarganya sebagai kepala daerah demi mempertahankan kekuasaan atau jabatan kepala daerah yang sedang diduduki atau dikuasai.

Kedua, akses. Politik dinasti juga terjadi karena faktor akses politik terutama akses politik terhadap partai politik. Akses terhadap partai politik menjadi salah satu faktor penentu suburnya politik dinasti mengingat partai politik cenderung memberikan rekomendasi kepada seseorang untuk maju sebagai calon kepala daerah karena seseorang tersebut di dorong/digaransi oleh orang yang sedang berkuasa. Akses penguasa (kepala daerah, Presiden, dan menteri) terhadap partai politik tentu sudah terbangun sejak lama sehingga memudahkan penguasa untuk memperoleh rekomendasi partai politik bagi anggota keluarganya yang akan dicalonkan sebagai kepala daerah.

Ketiga, modal. Politik dinasti semakin subur karena faktor kekuatan finansial. Seseorang yang sedang berkuasa tentu memiliki finansial yang sangat berlimpah sehingga memudahkan untuk melanjutkan politik dinasti. Kekuatan finansial yang dimiliki dapat digunakan untuk kebutuhan akomodasi politik mulai dari tahapan proses pencalonan sampai pemilihan. Diakui atau tidak, dalam konteks Pilkada di Indonesia, dibutuhkan dana yang tidak sedikit. Untuk biaya saksi pada tiap Tempat Pemunugutan Suara (TPS) saja dalam Pilkada untuk Kabupaten/Kota dibutuhkan dana miliaran apalagi untuk Pilkada untuk tingkat Provinsi (Gubernur) dibutuhkan dana sekitar 200 Milyar.

Keempat; Pola rekomendasi Parpol. Suburnya politik dinasti juga dipicu oleh pola rekomendasi partai politik. Sampai saat ini, partai politik belum memiliki pola yang pasti tentang rekomendasi bagi pasangan calon kepala daerah dan wakil kepala daerah. Tidak adannya pola 
pasti yang dimiliki Partai politik dalam memberikan rekomendasi terhadap siapa yang akan diusung sebagai calon kepala daerah atau wakil kepala daerah merupakan keuntungan bagi seorang penguasa untuk mencalonkan anggota keluarganya. Hal ini berbeda jika seandainya partai politik memiliki pola kaderisasi yang baik dimana rekomendasi partai politik akan diberikan kepada orang atau kader yang memiliki loyalitas dan telah menjalani proses kaderisasi di suatu partai politik.

Kelima, kondisi pemilih dalam Pilkada masih terbilang cukup awam. Kondisi ini tentu memudahkan penguasa untuk memenangkan anggota keluarganya. Kondisi pemilih yang awam sangat mudah dipengaruhi oleh penguasa untuk memilih anggota keluarganya.

Keenam, politik dinasti tetap subur atau tidak dapat dibendung karena politik dinasti merupakan politik yang tidak dilarang oleh ketentuan peraturan perundang-undangan. Peraturan perundangan-undangan khususnya undang-undang Pilkada tidak melarang anggota keluarga dari penguasa dan/atau kepala daerah yang sedang menjabat untuk mencalonkan diri sebagai calon kepala daerah. Upaya untuk membendung politik dinasti atau majunya seorang calon kepala daerah yang notabenenya memiliki hubungan keluarga dengan kepala daerah yang sedang menjabat pernah dilakukan melalui ketentuan Pasal 7 huruf r UU 8 tahun 2015 Tentang Pilkada yang menyatakan bahwa "tidak memiliki konflik kepentingan dengan petahana (Yang dimaksud dengan "tidak memiliki konflik kepentingan dengan petahana" adalah tidak memiliki hubungan darah, ikatan perkawinan dan/atau garis keturunan 1 (satu) tingkat lurus ke atas, ke bawah, ke samping dengan petahana yaitu ayah, ibu, mertua, paman, bibi, kakak, adik, ipar, anak, menantu kecuali telah melewati jeda 1 (satu) kali masa jabatan.)". Namun, pengaturan tentang pembatasan politik dinasti tersebut dibatalkan oleh Mahkamah Konstitusi pada tahun. ${ }^{5}$ MK mendalilkan bahwa:

Ketujuh, Hak Asasi Manusia. Suburnya politik dinasti juga berkaitan dengan hak asasi setiap warga Negara. ${ }^{6}$ Setiap warga Negara berhak untuk dipilih dan memilih dalam pemilihan kepala daerah. Artinya, siapapun orang

${ }^{5}$ https://www.republika.co.id/berita/koran/poli tik-koran/15/07/09/nr7nka31-mk-bolehkandinasti-politik, diakses tanggal 13 Agustus 2020, pukul 10.00 WIB

${ }^{6}$ Ahmad Siboy, Jangan Rampas Hak Istana Dalam Pilkada, Duta Masyarakat, Rabu 12 Februari 2020, hlm. 02 
yang ingin maju atau diajukan untuk mencalonkan diri dalam Pilkada tidak boleh dihalang-halangi walaupun yang bersangkutan merupakan anggota keluarga dari penguasa/kepala daerah yang sedang menjabat. Sebaliknya, larangan bagi anggota keluarga penguasa untuk maju sebagai calon kepala daerah merupakan perampasan hak konstitusional warga Negara atau bertentangan dengan prinsip-prinsip HAM.

Kedelapan, Pemilih di Indonesia khususnya pemilih yang berada di daerah-daerah tradisionalis masih paternalistik terhadap seseorang. Anggota keluarga penguasa dinilai telah memiliki kompetensi alami untuk menjadi seorang pemimpin. Biasanya, pemilih yang memiliki keyakinan model paternalistik adalah pemilih yang melihat bahwa transisi kepemimpinan haruslah berdasarkan pada garis keturunan.

Akibat dari sekian faktor tersebut maka tidak heran apabila terdapat banyak Pilkada ditingkat daerah yang calonnya merupakan anggota keluarga dari penguasa. Berikut adalah tabelnya:

Tabel 1

Pemilihan Kepala Daerah Dengan Calon Dari Anggota Keluarga Penguasa

\begin{tabular}{|c|c|c|c|}
\hline No & Daerah & $\begin{array}{l}\text { Nama } \\
\text { Calon }\end{array}$ & Keterangan \\
\hline 1 & Surakarta & $\begin{array}{l}\text { Gibran } \\
\text { Rakabumin } \\
\text { g Raka }\end{array}$ & $\begin{array}{l}\text { Putra } \\
\text { Presiden } \\
\text { (Jokowi) }\end{array}$ \\
\hline 2 & $\begin{array}{l}\text { Kota } \\
\text { Medan }\end{array}$ & $\begin{array}{l}\text { Bobby Afif } \\
\text { Nasution }\end{array}$ & $\begin{array}{l}\text { Putra } \\
\text { Presiden } \\
\text { (Jokowi) }\end{array}$ \\
\hline 3 & $\begin{array}{l}\text { Tangerang } \\
\text { Selatan }\end{array}$ & $\begin{array}{l}\text { 1. Rahayu } \\
\text { Saraswati; } \\
\text { 2. Siti Nur } \\
\text { Azizah. }\end{array}$ & $\begin{array}{l}\text { 1. } \\
\text { Keponakan } \\
\text { Menteri } \\
\text { Pertahanan } \\
\text { (Prabowo } \\
\text { Subianto); } \\
2 . \quad \text { Putri } \\
\text { Wakil } \\
\text { Presiden } \\
\text { (Ma'ruf } \\
\text { Amin). }\end{array}$ \\
\hline 4 & Kediri & $\begin{array}{l}\text { Hanindhito } \\
\text { Himawan } \\
\text { Pramana }\end{array}$ & $\begin{array}{l}\text { Putra dari } \\
\text { Sekretaris } \\
\text { Kabinet } \\
\text { (Pramono } \\
\text { Anung) }\end{array}$ \\
\hline 5 & $\begin{array}{l}\text { Provinsi } \\
\text { Kepulaun } \\
\text { Riau }\end{array}$ & $\begin{array}{l}\text { Marlin } \\
\text { Agustina }\end{array}$ & $\begin{array}{l}\text { istri dari } \\
\text { Wali Kota } \\
\text { Batam, } \\
\text { Muhammad } \\
\text { Rudi }\end{array}$ \\
\hline 6 & $\begin{array}{l}\text { Indragiri } \\
\text { Hulu }\end{array}$ & $\begin{array}{l}\text { Rezita } \\
\text { Melyani }\end{array}$ & $\begin{array}{l}\text { istri dari } \\
\text { Bupati } \\
\text { Indragiri } \\
\text { Hulu, Riau, } \\
\text { (Yopi } \\
\text { Arianto) }\end{array}$ \\
\hline 7 & Serang & $\begin{array}{l}\text { Ratu Tatu } \\
\text { Chasanah }\end{array}$ & $\begin{array}{l}\text { Adik } \\
\text { kandung } \\
\text { dari mantan } \\
\text { Gubernur } \\
\text { Banten } \\
\text { (Ratu Atut } \\
\text { Chosiyah). } \\
\end{array}$ \\
\hline 8 & Sleman & Kustini Sri & istri dari \\
\hline
\end{tabular}




\begin{tabular}{|c|c|c|c|}
\hline & & Purnomo & $\begin{array}{l}\text { Bupati } \\
\text { Sleman ( Sri } \\
\text { Purnomo). }\end{array}$ \\
\hline 9 & $\begin{array}{l}\text { Banyuwan } \\
\text { gi }\end{array}$ & $\begin{array}{l}\text { Ipuk } \\
\text { Fiestiandani }\end{array}$ & $\begin{array}{l}\text { istri dari } \\
\text { Bupati } \\
\text { Banyuwa- } \\
\text { ngi, (Azwar } \\
\text { Anas). }\end{array}$ \\
\hline 10 & Makassar & $\begin{array}{l}\text { Irman Yasin } \\
\text { Limpo }\end{array}$ & $\begin{array}{l}\text { Adik } \\
\text { Menteri } \\
\text { Pertanian } \\
\text { (Syahrul } \\
\text { Yasin } \\
\text { Limpo) } \\
\end{array}$ \\
\hline 11 & $\begin{array}{l}\text { Pangkajen } \\
\text { e dan } \\
\text { Kepulauan }\end{array}$ & $\begin{array}{l}\text { Muhammad } \\
\text { Yusron } \\
\text { Lagogau. }\end{array}$ & $\begin{array}{l}\text { keponakan } \\
\text { dari Bupati } \\
\text { Pangkajene } \\
\text { dan } \\
\text { Kepulauan } \\
\text { (Syamsudin } \\
\text { A Hamid) }\end{array}$ \\
\hline 12 & Sijunjung & $\begin{array}{l}\text { Benny } \\
\text { Dwifa } \\
\text { Yuswir. }\end{array}$ & $\begin{array}{l}\text { Anak dari } \\
\text { Bupati } \\
\text { Sijunjung } \\
\text { (Yuswir } \\
\text { Arifin) }\end{array}$ \\
\hline 13 & $\begin{array}{l}\text { Buru } \\
\text { Selatan, } \\
\text { Maluku }\end{array}$ & $\begin{array}{l}\text { Safitri } \\
\text { Malik } \\
\text { Soulisa }\end{array}$ & $\begin{array}{l}\text { Istri dari } \\
\text { Bupati Buru } \\
\text { Selatan } \\
\text { (Tagop } \\
\text { Sudarsono } \\
\text { Soulisa). } \\
\end{array}$ \\
\hline
\end{tabular}

\section{Implikasi Politik Dinasti}

Pada sisi yang berbeda, munculnya calon kepala daerah dari anggota keluarga penguasa maka akan menimbulkan berbagai impilikasi

\footnotetext{
${ }^{7}$ https://www.kompas.com/tren/read/2020/12 10/203500065/perolehan-suara-sementaradinasti-politik-pilkada-2020-di-13-daerahmulai?page=all, diakses tanggal 15 Desember 2020, pukul 17.15 WIB
}

diantaranya pertama, anggota keluarga yang dicalonkan oleh orang yang sedang memiliki kekuasaan atau menduduki jabatan di pemerintahan hanya menjadi calon kepala daerah "boneka" atau bayangan.

Kedua, anggota keluarga yang dicalonkan oleh penguasa kerapkali merupakan orang yang belum memiliki kompetensi yang memadai untuk menjadi seorang kepala daerah/wakil kepala daerah.

Ketiga, Implikasi dari politik dinasti juga diwarnai oleh munculnya pemaksaan terhadap anggota keluarga dari penguasa untuk mencalonkan diri dalam Pilkada padahal yang bersangkutan merasa tidak berbakat dan memiliki keinginan untuk mencalonkan diri. Namun, yang bersangkutan tetap dipaksa untuk maju demi menjaga atau melanjutkan trah politik dinasti.

Keempat. kematian pola kaderisasi Parpol. Munculnya politik dinasti juga berimplikasi pada matinya kaderisasi di suatu partai politik. Sebab, tatkala penentuan calon kepala daerah didasarkan pada hubungan kekeluargaan maka secara otomatis proses kaderisasi yang berjalan di Parpol akan mati. Hal ini terjadi karena siapapun yang menjalani proses dari bawah di suatu Parpol dan dalam waktu yang relatif 
lama tidak memiliki nilai apa-apa apabila bukan anggota keluarga dari penguasa. Dalam hal ini dapat diambil contoh dalam Pilkada Kota Solo Tahun 2020, dimana terdapat dua orang yang mengajukan rekomendasi untuk dicalonkan oleh Partai Demokrasi Indoensia Perjuangan (PDI-P) yakni Achmad Purnomo dan Gibran Rakabuming Raka. Achmad Purnomo merupakan orang yang sudah lama menjadi kader PDI-P Kota Solo sehingga Achmad Purnomo yang layak untuk dicalonkan oleh PDI-P. Namun, rekomendasi PDI-P justru diberikan kepada Gibran Rakabuming Raka. Jatuhnya rekomendasi PDI-P kepada Gibran Rakabuming Raka tidak lepas dari status Gibran yang merupakan putra dari Presiden Joko Widodo. ${ }^{8}$ Dalam konteks ini maka sangat tampak bahwa hubungan kekeluargaan dengan penguasa lebih utama dan penting ketimbang berproses menjadi kader di suatu partai politik.

Kelima, kompetisi tidak sehat. Majunya anggota keluarga dari penguasa tentu akan menjadikan kompetisi tidak sehat. Kompetisi tidak

${ }^{8} \mathrm{https}: / /$ regional.kompas.com/read/2020/07/ 17/17420161/gibran-rekomendasi-ini-bagisaya-suatu-kehormatan, diakses tanggal 19 November 2020, pukul 12.20 WIB sehat karena calon kepala daerah yang merupakan bagian dari keluarga penguasa pasti akan mendapatkan keistimewaan tertentu. Keistimewaan ini yang kemudian menyebabkan kompetisi antar peserta Pilkada menjadi tidak berimbang. Sementara peserta Pilkada yang menjadi kompetitor dari calon yang merupakan anggota keluarga penguasa akan dipersulit dari berbagai sisi bahkan berpotensi akan sering mengalami sabotase.

\section{Desain Upaya Penguatan Politik Dinasti}

Kehadiran politik dinasti dalam setiap Pilkada merupakan hal yang tidak dielakkan. Melarang adanya politik dinasti merupakan hal yang bertentangan dengan hakikat kebebasan berpendapat dan berserikat yang dijamin oleh konstitusi. Di sisi lain, membiarkan dinamika politik dinasti seperti dalam Pilkada-Pilkada sebelumnya tentu bertentangan dengan spirit demokrasi langsung yang dianut di Indonesia. Substansi demokrasi yang diharapkan dari penyelenggaraan Pilkada langsung menjadi suatu yang semakin sulit terwujud. Dinamika politik dinasti yang telah berlangsung selama beberapa kali penyelenggaraan Pilkada serentak telah melahirkan kepala daerah yang tidak 
merefresentasikan kehendak rakyat. Atas situasi seperti inilah kemudian maka perlu dilakukan berbagai desain untuk tetap memastikan Pilkada tetap berjalan demokratis walaupun terdapat anggota keluarga penguasa yang mencalonkan diri sebagai peserta Pilkada.

Artinya, politik dinasti dalam Pilkada tidak perlu dilarang karena berkaitan dengan hak asasi setiap warga Negara sehingga yang perlu diperbaiki adalah bagaimana sistem Pilkada yang dapat mencegah politik dinasti yang tidak berkualitas dan merugikan prinsipprinsip demokrasi. Dalam konteks ini maka perlu didesain suatu penyelenggaraan Pilkada dimana politik dinasti dapat menjadi politik yang tetap berjalan sesuai dengan harapan dan nilai-nilai yang terkandung dalam penyelenggaraan Pilkada. Artinya, walaupun terjadi politik dinasti namun politik dinasti tersebut tetap dibangun dan didasarkan pada cita-cita, out put dan outcome dari Pilkada.

Salah satu mekanisme untuk mewujudkan politik dinasti yang ideal dapat diwujudkan dalam beberapa hal yang meliputi persyaratan, pengaturan, Rekomendasi Parpol, Netralitas ASN, Profesionalisme Penyelenggara Dan Rasionalitas Pemilih.

\section{a. Persyaratan}

Pertama, persyaratan, Persyaratan menjadi peserta pemilihan merupakan langkah utama untuk mencegah munculnya calon kepala daerah yang hanya beorienstasi melanjutkan dinasti politik. Dengan persyaratan yang ketat maka secara otomatis munculnya calon yang berasal dari keluarga penguasa dapat diminimalisir atau bahkan penguasa akan berfikir ulang untuk menentukan siapa yang akan dicalonkan. Dengan penguatan persyaratan menjadi peserta Pilkada maka otomatis semua calon harus memenuhi persyaratan yang ketat tersebut sehingga apabila terdapat pasangan calon yang sekedar dipasang oleh anggota keluarga penguasa sebagai boneka maka otomatis calon bersangkutan tidak akan memenuhi persyaratan sebagai calon kepala daerah. Disini dapat disimpulkan persyaratan sebagai peserta Pilkada akan menjadi screening awal untuk membendung politik dinasti yang tidak berkualitas.

Apabila persyaratan untuk menjadi peserta Pilkada tidak dibuat secara ketat maka tentu kedudukan persyaratan dalam Pilkada untuk mencegah politik dinasti yang buruk tidak dapat terwujud. Persyaratan memiliki kedudukan yang sangat signifikan dalam melakukan penyaringan dan pencegahan terhadap 
politik dinasti yang buruk karena persyaratan merupakan alat yang sah atau legal dalam membatasi hak seseorang untuk maju dalam Pilkada. Dalam dinamika politik dinasti misalnya, calon kepala daerah yang diusung oleh penguasa dan tidak memenuhi kriteria atau persyaratan yang telah ditetapkan oleh peraturan perundang-undangan maka otomatis bakal calon kepala daerah tersebut dapat didiskualifikasi.

Dari kedudukan persyaratan itulah maka persyaratan sebagai calon kepala daerah harus benar-benar merepresentasikan nilai-nilai yang melatar belakangi tujuan penyelenggaraan Pilkada. Terdapat beberapa unsur yang harus diperhatikan untuk membentuk aturan tentang persyaratan peserta Pilkada: Pertama, kualitas bakal calon. Persyaratan sebagai calon kepala daerah juga harus mmengakomodir atau memastikan bahwa calon kepala daerah yang memenuhi persyaratan merupakan orang-orang yang benar-benar memiliki kualitas sebagai calon kepala daerah. Dengan terdapatnya unsur kualitas sebagai syarat calon peserta Pilkada maka otomatis calon kepala daerah terutama calon kepala daerah yang merupakan anggota keluarga penguasa merupakan orang-orang yang memiliki kualitas untuk menjadi seorang kepala daerah. Parameter dari unsur kualitas ini dapat dilihat dari pendidikan seorang calon kepala daerah. Latar belakang pendidikan menjadi salah satu parameter yang dapat merefresentasikan kualitas calon kepala daerah karena pendidikan merupakan bukti nyata bahwa sesorang telah menempa dirinya melalui proses pendidikan dimana proses pendidikan sendiri merupakan ruang formal yang terbukti dapat meningkatkan kualitas manusia. Sangat sulit untuk mengukur kualitas manusia apabila orang tersebut tidak memiliki latar pendidikan. Kualitas seseorang tanpa melalui proses pendidikan akan menyebabkan sulitnya mencari legitimasi yang tepat bahwa orang tersebut adalah orang yang berpendidikan.

Dalam penentuan syarat kualitas seseorang dengan menggunakan latar belakang pendidikan dalam perumusan norma hukum pada peraturan perundang-undangan dalam Pilkada tentu sangatlah mudah. Semisal menyatakan bahwa seorang calon kepala daerah minimal berpendidikan sarjana atau magister. Dengan persyaratan latar belakang pendidikan ini maka munculnya calon kepala daerah yang tidak berkualitas atau tidak memiliki 
latar belakang pendidikan akan terdiskualifikasi dengan sendirinya.

Kedua, integritas, unsur kedua dalam persyaratan calon kepala daerah adalah integritas. Integritas dalam konteks ini berkaitan dengan pola pikir dan pola sikap seorang calon kepala daerah yang jujur dan bersih serta bertanggung jawab. Syarat integritas ini mutlak bagi calon kepala daerah karena seorang calon kepala daerah apabila terpilih akan menjadi pemimpin untuk banyak orang sehingga seorang kepala daerah harus menjadi orang yang memiliki pola pikir dan pola sikap yang lurus untuk bekerja demi kepentingan rakyat bukan untuk kepentingan diri sendiri atau kelompoknya. Dengan adanya unsur integritas ini maka seorang calon kepala daerah yang berasal dari keluarga penguasa sekalipun juga merupakan orang yang memiliki integritas sebab apabila keluarga penguasa mengutus anggota keluarganya yang tidak memiliki integritas maka otomatis orang tersebut tidak akan memenuhi persyaratan sebagai calon kepala daerah.

Parameter untuk mengukur persyaratan integritas sebagai calon kepala daerah tentu tidaklah mudah. Sebab, integritas merupakan keadaan hati dan pikiran seseorang yang bersifat absrak sehingga sangat sulit untuk diketahui oleh orang lain. Penempatan persyaratan integritas sebagai syarat calon kepala daerah tentu akan menjadi debatable dalam hal pembuktiannya mengingat semua orang akan selalu merasa dan menyatakan bahwa dirinya adalah orang yang berintegritas. Namun, problematika ini dapat diselesaikan dengan menggunakan beberapa kriteria integritas seperti kriteria integritas yang dikemukana oleh Rogers (1961). Dimana intergritas dapat dilihat dari konsistensi terhadap komitmen sedangkan komitmen mencerminkan prinsip, motivasi, keyakinan, perasaan, logika, tindakan, identitas dan regulasi diri. Konsistensi menunjukkan kesatuan terhadap semua hal tersebut. Perilaku yang terlihat merupakan wujud tanggung jawab individu terhadap orang lain dan norma, serta bukan karena pertimbangan untung dan rugi. ${ }^{9}$

Integritas juga dapat dilihat secara nyata dalam rekam jejak bagi calon kepala daerah, rekam jejak tersebut seperti keterlibatan seorang calon kepala daerah dalam kasus hukum. Keterlibatan seseorang dalam kasus hukum tentu

9 Masitah, 2012, Construction of Integrity ScaleUsing Polytomous Item Response Theory Model: Study In Job Environment, Depok, Fakultas Psikologi UI, hlm.10-12 
merupakan perwujudan kongkrit bahwa orang tersebut tidak memiliki integritas mengingat orang-orang yang berintegritas tentu tidak akan melakukan perbuatan yang dilarang oleh hukum. Perbuatan melanggar hukum merupakan perbuatan yang tercela secara moral (hati) dan perilaku (fisik). Perbuatan melanggar hukum tidak akan dilakukan oleh seseorang apabila hatinya bersih dan perilakunya jujur.

Salah satu upaya untuk menghadirkan calon kepala daerah berintegritas (termasuk dari keluarga penguasa) yang telah dilakukan ialah dengan melakukan pembatasan bagi calon kepala daerah yang pernah terlibat kasus korupsi. Seseorang yang pernah terlibat kasus korupsi dan telah memiliki kekuatan hukum mengikat (inracht) tidak diperkenankan untuk mengajukan diri sebagai calon kepala daerah. Pembatasan bagi seseorang yang pernah terlibat kasus korupsi untuk menjadi calon kepala daerah tentu merupakan upaya untuk melahirkan kepala daerah yang berintegritas.

Namun, larangan bagi seseorang yang pernah terlibat kasus korupsi sebagai calon kepala daerah ini tidak berlaku secara mutlak. Artinya, masih terdapat pengecualian-pengecualian dimana seseorang yang pernah terlibat kasus hukum seperti korupsi tetap dapat menjadi calon kepala daerah. Seseorang yang pernah terlibat kasus korupsi tetap dapat mencalonkan diri sebagai calon kepala daerah selama yang bersangkutan telah selesai menjalani hukuman penjara dan mengumumkan kepada publik bahwa dirinya adalah mantan narapida korupsi.

Integritas bagi calon kepala daerah juga dapat diukur melalui persyaratan telah memiliki pengalaman bekerja. Seseorang dapat teruji integritasnya apabila sudah pernah bekerja. Artinya, apabila seseorang benar-benar tidak terlibat berbagai kasus saat bekerja maka secara otomatis orang tersebut dapat dinyatakan berintegritas karena telah lolos dari ujian. Hal ini berbeda dengan orang yang belum memiliki pengalaman bekerja sama sekali. Orang yang belum memiliki pengalamn kerja tentu sangat sulit untuk diketahui yang bersangkutan berintegritas atau tidak mengingat seseorang dapat teruji integritasnya apabila mampu melewati ujian di dunia kerja. Kadangkala orang sangat kritis, memiliki idealisme yang sangat tinggi saat berbicara dan berpidato namun saat sudah menjadi penguasa yang bersangkutan malah terjerat kasus korupsi. Hal ini tentu menunjukkan bahwa integritas orang tersebut hanya 
berada di dunia kata-kata namun lumpuh di dunia kerja atau dapat dikatakan bahwa orang tersebut tidak memiliki integritas.

Persyaratan pengalaman kerja ini tentu akan menjadi cara yang sangat ampuh dalam membendung calon dinasti yang tidak berkualitas. Sebab, calon kepala daerah yang merupakan anggota keluarga dari penguasa harus pernah memiliki pengalaman kerja sehingga calon kepala daerah yang tidak siap namun dipaksa untuk mencalonkan diri oleh keluarganya tidak akan memenuhi syarat. Syarat memiliki pengalaman kerja ini tentu juga memaksa penguasa untuk mencalonkan orang atau anggota keluarganya yang sudah memiliki pengalaman. Dengan demikian maka calon yang diajukan oleh keluarga penguasa tentu merupakan orang yang memenuhi pengalaman kerja.

Namun, segala persyaratan yang digunakan untuk mencegah politik dinasti yang tidak berkualitas tidak boleh diskriminatif. Persyaratan tersebut tidak boleh hanya diberlakukan untuk calon kepala daerah yang berasal dari keluarga penguasa saja. Sifat persyaratan harus diberlakukan sama untuk seluruh calon peserta Pilkada (equality before the law). 


\section{c. Rekomendasi Parpol}

Rekomendasi Partai politik merupakan kunci utama untuk mencegah calon dari keluarga penguasa yang tidak berkuliatas. Sebagaimana mafhum, bahwa rekomendasi Parpol yang dapat menentukan seseorang dapat maju sebagai calon kepala daerah/wakil kepal daerah. Sebagai pemengang rekomendasi maka partai politik dapat melakukan screening secara mutlak untuk memastikan bahwa calon kepala daerah yang berasal dari keluarga istana adalah orang yang benar-benar refresentatif. Langkah-langkah Parpol dalam mewujudkan hadirnya calon kepala daerah dari keluarga penguasa adalah: Pertama, partai politik harus dapat melakukan lobi-lobi dan memilih siapa yang tepat untuk dicalonkan dari anggota keluarga penguasa. Diakui atau tidak, anggota keluarga penguasa tentu tidak hanya satu orang. Artinya, bisa saja terdapat istri, saudara kandung dan anak. Partai politik dapat terlebih dahulu melakukan pemetaan atas kualitas dari seluruh keluarga penguasa dan menentukan siapa yang paling tepat dan memenuhi prinsip-prinsip Pilkada. Permintaan partai politik kepada penguasa tentu akan sangat mempengaruhi tentang siapa yang akan melanjutkan trah penguasa dalam
Pilkada. Penguasa tentu akan berkomrpomi dengan permintaan partai politik karena penguasa yang sedang menjabat sadar betul bahwa partai politik sangat penting baginya mengingat apabila tidak terdapat jalan kompromi antara penguasa dengan partai politik maka mimpi untuk melanjutkan trah politik keluarganya dalam Pilkada akan sia-sia bahkan menjadi ancaman karena suatu partai politik dapat memgalihkan dukungan pada pasangan atau calon lain.

Kedua, profesionalisme Partai politik. Partai politik harus profesional atau tidak boleh menjalin kontrak politik dengan penguasa sehingga partai politik mengabaikan profesionalismenya. Sikap ini penting dilakukan oleh partai politik. Diakui atau tidak, suburnya politik dinasti yang tidak berkualitas juga dipengaruhi oleh sifat partai politik yang tidak berdaya dihadapan penguasa. Sikap partai politik yang tidak berdaya dihadapan penguasa terlihat dimana partai politik sangat patuh atau sami'na wa athonak terhadap keinginan penguasa tentang siapa yang akan diusung sebagai calon kepala daerah. Partai politik tidak melakukan penilaian terhadap calon yang diajukan oleh penguasa. Partai politik tidak berdaya menghadapi penguasa. Bagi Parpol, 
siapapun calon yang diajukan oleh penguasa maka harus disetujui demi menjaga relasi parpol dengan penguasa. Hal inilah yang kemudian menyebabkan penguasa sembarangan menunjuk anggota keluarganya untuk diajukan sebagai calon kepala daerah.

Ketiga, Parpol harus mampu meyakinkann penguasa bahwa dirinya (Parpol) tetap akan mengusung calon yang diajukan penguasa atau keluarga penguasa selama calon yang diajukan oleh penguasa sesuai dengan karakter dan visi misi Parpol. Artinya, walaupun partai politik terikat kontrak politik dengan penguasa namun partai politik harus tetap menjaga visi dan misi Parpol-nya. Partai politik harus tegas bahwa ia akan tetap mendukung keluarga penguasa dalam Pilkada jikalau calon yang diajukan merupakan orang yang memenuhi standart kriteria Parpol. Dengan demikian maka calon yang akan diajukan oleh penguasa adalah calon yang relatif refresentatif mengingat visi dan misi Parpol selalu ideal sehingga apabila calon yang diajukan sesuai dengan visi dan misi Parpol maka secara otomatis calon yang akan diajukan sebagai peserta Pilkada adalah calon yang ideal. Apabila partai politik merasa bahwa calon yang berasal dari kelaurga penguasa tidak sesuai dengan visi dan misi partainya maka partai politik dapat menolak calon yang diajukan penguasa untuk diganti atau bahkan menarik dukungannya.

\section{d. Netralitas Aparatur Sipil Negara}

Aparatur Sipil Negara (ASN) merupakan penyelenggara Negara yang dilarang terlibat dalam pemilihan kepala daerah. ${ }^{10}$ Apabila seorang ASN diketahui dan terbukti terlibat dalam kegiatan politik praktis seperti Pilkada maka yang bersangkkutan akan mendapatkan sanksi berupa pemecatan. Namun dalam prakteknya, seringkali ditemukan keterlibatan ASN dalam Pilkada. Keterlibatan ASN dalam Pilkada tentu dalam rangka untuk menyuskseskan keluarga kepala daerah atau penguasa dalam Pilkada. ASN terlibat dalam aktivitas mendukung anggota keluarga penguasa karena seringkali ASN terikat janji politik dengan kepala daerah atau penguasa atau bahkan karena terpaksa. Diakui atau tidak, ASN terpaksa menjadi "tim sukses gelap" anggota keluarga penguasa yang sedang mencalonkan diri dalam Pilkada karena ASN bersangkutan dituntut untuk menjadi mesin politik yang dapat meraup suara demi kemenangan calon kepala daerah

10 UU No. 5 Tahun 2014 tentang Aparatur Sipil Negara Pasal 2 huruf $d$ 
yang berasal dari anggota keluarga penguasa. Apabila ASN tersebut menolak untuk membantu memenangkan calon kepala daerah yang merupakan keluarga penguasa maka ASN tersebut berpotensi untuk dimutasi atau dipindah oleh kepala daerah yang sedang menjabat. Ketakutan akan mutasi inilah yang kemudian menyebabkan ASN terpaksa mendukung calon kepala daerah yang merupakan keluarga penguasa.

Di sisi lain, ASN juga menjadi pendukung militan calon kepala daerah yang merupakan keluarga penguasa karena sebagai bentuk politik balas budi. Politik balas budi antara ASN dengan penguasa khususnya kepala daerah yang sedang menjabat, terjadi karena seorang ASN dinaikkan jabatannya dengan konvensasi berupa dukungan terhadap calon kepala daerah yang berasal dari keluarga kepala daerah yang sedang menjabat. Modus yang dilakukan ialah seorang kepala daerah mengangkat A menjadi kepala dinas. Jabatan kepala dinas ini diberikan kepada A dengan syarat A pada saat Pilkada membantu memenangkan calon kepala daerah baik putra/anngota keluarga kepala daerah yang sedang menjabat tersebut.

Sebenarnya, modus kepala daerah atau penguasa untuk memanfaatkan
ASN sebagai "tim sukses terselubung" telah diantisipasi dengan larangan mutasi jabatan oleh kepala daerah menjelang Pilkada. Pasal 71 ayat (2) UU 10 tahun 2016 Tentang Pilkada menyatakan bahwa Gubernur atau Wakil Gubernur, Bupati atau Wakil Bupati, dan Walikota atau Wakil Walikota dilarang melakukan penggantian pejabat 6 (enam) bulan sebelum tanggal penetapan pasangan calon sampai dengan akhir masa jabatan kecuali mendapat persetujuan tertulis dari Menteri.

Oleh karena itu, maka ASN dapat mencegah terjadinya politik dinasti yang tidak berkualitas dalam Pilkada jikalau ASN menolak untuk mendukung anggota keluarga kepala daerah/penguasa dalam Pilkada. Penolakan ASN untuk tidak mendukung calon kepala daerah yang merupakan keluarga penguasa tentu dapat memupus keangkuhan kepala daerah atau penguasa untuk mencalonkan anggota keluarganya yang tidak pantas sebagai kepala daerah.

\section{e. Rakyat/Pemilih}

Rakyat atau pemilih merupakan ujung tombak untuk memastikan bahwa Pilkada yang diikuti oleh calon yang berasal dari keluarga penguasa tetap dapat berkualitas. Rakyat menjadi kunci 
karena calon kepala daerah yang berasal dari penguasa sekalipun sangat bergantung pada pilihan rakyat. Peran rakyat dalam mencegah politik dinasti yang tidak berkualitas dapat terwujud dalam beberapa hal. Pertama, apabila rakyat tidak menghendaki calon yang ditawarkan oleh penguasa baik itu istrinya, anaknya atau saudaranya maka rakyat dapat menyuarakan penolakannya apabila ada survey tentang popularitas dan elektabilitas calon kepala daerah di daerahnya. Rakyat dapat menyatakan penolakannya dengan memberikan jawaban "tidak" pada saat diinterview atau mengisi kusioner dari lembaga survey. Hasil survey yang sangat rendah terhadap bakal calon kepala daerah yang diajukan oleh penguasa atau kepala daerah yang sedang menjabat tentu akan membuat penguasa berfikir ulang untuk memaksakan calon yang diajukan untuk terus maju dalam Pilkada. Artinya, penguasa akan mencari alternatif calon lain dari keluarganya apabila calon yang diajukannya diprediksi akan kalah. Penguasa atau kepala daerah yang sedang menjabat tentu tetap akan berfikir realistis terutama tentang potensi kemenangan calon yang didukungnya. Salah satu parameter yang digunakan penguasa atau kepala daerah yang sedang menjabat tentu adalah hasil survey. Dalam dinamika pemilihan modern yang digelar secara langsung, hasiil survey merupakan salah satu tolak ukur utama yang digunakan oleh berbagai pihak untuk menentukan siapa yang akan diusung dalam Pilkada. Tentu saja, bakal calon yang elektabilitasnya rendah tidak akan dipaksakan untuk diajukan sebagai peserta Pilkada. Sebab, memaksakan calon kepala daerah yang elektabilitasnya rendah tentu sama persis dengan mengusung calon yang akan tumbang atau kalah dalam Pilkada. Rendahnya elektabilitas calon kepala daerah yang merupakan anggota keluarga penguasa adalah potret bahwa calon yang diakui oleh penguasa tidak dikehendaki rakyat sebagai pemegang hak pilih. Mau tidak mau, Penguasa atau kepala daerah yang sedang menjabat tentu juga harus memikirkan arus suara rakyat jika tetap ingin melangengkan kekuasaan keluarganya (politik dinasti). Jalur kompromi harus ditempuh antara penguasa dengan rakyat karena rakyatlah yang memiliki hak pilih dimana apabila rakyat menolak memilih calon yang diajukan oleh penguasa maka mimpi penguasa untuk melanjutkan kekuasaannya lewat orang lain akan sia-sia. Kuasa rakyat sangat besar untuk meruntuhkan kuasa politik penguasa atau dinasti. Sementara 
penguasa sendiri juga memiliki keterbatasan kekuasaan untuk memaksa rakyat memilih calon yang diusungnya mengingat proses penentuan pilihan oleh rakyat bersifat rahasia sehingga tidak dapat ditekan oleh pihak manapun termasuk oleh penguasa. Bersamaan dengan itu, kalaupun dalam Pilkada didaerah tersebut hanya diikuti oleh calon tunggal atau hanya calon yang merupakan anggota keluarga dari penguasa akan tetapi rakyat tetap dapat menolakknya sehingga yang akan memenangi Pilkada adalah lumbung kosong.

Rakyat sebagai pemilih juga dapat mengusung calon dari jalur perseorangan sebagai upaya untuk mencegah anggota keluarga dari penguasa yang dicalonkan bukanlah orang yang sembarangan. Rakyat yang mendukung calon perseorangan maka secara otomatis akan membuat penguasa benar-benar memilih sosok terbaik dari anggota keluarganya untuk diusung dalam Pilkada.

\section{f. Penyelengggara}

Penyelenggara pemilihan kepala daerah merupakan pihak yang juga bertangungjawab untuk memastikan bahwa calon yang diajukan oleh penguasa akan mendapatkan perlakuan yang sama dengan calon yang lain. Hal ini sangat penting agar supaya tidak ada jalur istimewa bagi anggota keluarga dari penguasa. Apabila penyelenggara Pilkada berprilaku professional maka secara otomatis pula calon kepala daerah yang akan diajukan oleh penguasa adalah orang yang berkualitas mengingat penyelenggara Negara tidak dapat diintervensi oleh penguasa sehingga kondisi ini membuat anggota keluarga dari penguasa yang maju dalam Pilkada akan menjalani proses sebagaiman mestinya. Ia akan berkompetisi secara utuh dengan calon lain sehingga posisi seorang calon kepala daerah yang berasal dari keluarga penguasa tidak memiliki efek atau menjadi jaminan untuk memenangi Pilkada atau diperlakukan istimewa dalam tiap tahapan penyelenggaraan Pilkada. Diakui atau tidak, mulusnya anggota keluarga penguasa dalam memenangi Pilkada seringkali juga karena perlakuan istimewa yang diberikan oleh penyelenggara.

Sikap profesional penyelenggara Pemilihan kepada calon kepala daerah yang berasal dari keluarga penguasa dapat ditunjukkan dengan ketegasan dalam semua tahapan penyelenggaraan terutama dalam penerapan dan penegakkan aturan Pilkada. Dalam hal penerapan aturan Pilkada maka 
penyelenggara Pilkada tidak boleh mengkompromikan ketentuan dalam setiap peraturan perundang-undangan kepada salah satu calon terutama calon yang berasal dari anggota keluarga penguasa.

Sedangkan dari sisi penegakkan maka penyelenggara Pilkada harus tegas untuk memberikan sanksi kepada calon kepala daerah yang berasal dari keluarga penguasa sekalipun. Selama ini, penyelenggara Pilkada kadangkala sangat takut untuk memberikan sanksi kepada calon kepala daerah yang merupakan anggota keluarga penguasa sehingga menyebabkan calon kepala daerah bersangkutan seringkali meremehkan kepatuhan terhadap ketentuan peraturan perundangundangan tentang penyelenggaraan Pilkada. Penyelenggara Pilkada mutlak memberikan perhatian khusus kepada calon kepala daerah yang berasal dari anggota keluarga penguasa karena calon yang demikianlah yang berpotensi besar untuk melakukan pelanggaran yang bersifat terstruktur, sistematis dan masif (TSM).

\section{Kesimpulan}

Politik dinasti menjadi hal yang tidak dapat dielakkan dalam Pilkada karena berbagai faktor seperti tidak dapatnya kepala daerah yang sedang menjabat untuk mencalonkan diri kembali karena sudah dua periode menduduki kursi kepala daerah sehingga memaksakan anggota keluarganya untuk maju sebagai orang yang akan mempertahankan kekuasaanya atau terdapat kerakusan dari pejabat ditingkat pusat yang ingin anggota keluarganya menjadi penguasa di daerah dan keinginan tersebut ditopang oleh akses politik dan modal yang memadai. Akibat dari pola pencalonan tersebut (politik dinasti) maka telah menyebabkan munculnya calon kepala daerah yang tidak memiliki kompetensi, hanya sekedar menjadi boneka, terpaksa sebagai calon kepala daerah. Bersamaan dengan itu, politik dinasti juga telah mematikan proses kaderisasi Parpol dan kompetensi yang tidak sehat dalam Pilkada. Namun, politik dinasti merupakan suatu hal yang tidak bisa dilarang karena pelarangan terhadap politik dinasti bertentangan dengan prinsip hak asasi setiap warga negara untuk menggunakan haknya dalam mengembangkan diri dalam pemerintahan. Dengan demikian maka yang perlu dilakukan bukanlah melarang politik dinasti melainkan bagaimana membuat Pilkada yang diikuti oleh dinasti politik tetap berada dalam 
hakikat penyelenggaraan Pilkada yang demokratis. Untuk mewujudkan Pilkada yang demikian maka dapat ditempuh dengan penguatan persyaratan bagi seluruh peserta Pilkada. Yakni harus terdapat penguatan persyaratan sehingga setiap bakal calon kepala daerah adalah orang terbaik. Bersmaan dengan itu, pola rekomendasi partai politik terhadap oorang yang akan diajukan sebagai calon kepala daerah harus dibenahi dan terdapat kepastian tidak ada pemanfaatan Aparatur Sipil Negara.

\section{Daftar Pustaka}

\section{Buku}

Ahmad Siboy, Kontruksi Hukum Pilkada: Jalan Tengah Keadilan Prosedural dan Substansial Dalam Penyelesaian Perselisihan Hasil Pilkada Serentak, Depok : Rajawali Pres, 2018.

Tjahjo Kumolo, Politik Hukum Pilkada Serentak, Jakarta : Expose, 2015

Johny Ibrahim, Teori Dan Metodologi Penelitian Hukum Normatif, Malang : Bayu Media Publishing, 2008.

Masitah, Construction of Integrity ScaleUsing Polytomous Item Response Theory Model: Study In Job Environment, Depok, Fakultas Psikologi UI, 2012.

\section{Karya Ilmiah}

Sodikin, Kedaulatan Rakyat dan Pemilihan Kepala Daerah Dalam Konteks Undang-Undang Dasar Negara Republik Indonesia Tahun 1945, Jurnal Cita Hukum, Vol. II No. 1 Juni 2014.

Nyoman Mas Aryani dan Bagus Hermanto, Justification of Political Rights of Ex-Convicted: Human Rights and Statutory Law Perspectives, Jurnal Konstitusi, Volume 17, Nomor 2, Juni 2020.

Ahmad Siboy, Jangan Rampas Hak Istana Dalam Pilkada, Duta Masyarakat, Rabu 12 Februari 2020.

\section{Website}

https://nasional.kompas.com/read/2020/ 09/01/17432151/70-bapaslonpenuhi-syarat-sebagai-calonperseorangan-pilkada-inirinciannya?page $=$ all, $\quad$ diakses tanggal 13 November 2020, pukul 13.20 WIB

https://memorandum.co.id/dpp-hanurarekom-fattah-jasin-di-pilkadasumenep-dpc-membantah/, diakses tanggal 20 November 2020, pukul 15.00 WIB

https://www.republika.co.id/berita/koran /politik-koran/15/07/09/nr7nka31mk-bolehkan-dinasti-politik, diakses tanggal 13 Agustus 2020, pukul 10.00 WIB

https://www.kompas.com/tren/read/2020 /12/10/203500065/perolehansuara-sementara-dinasti-politikpilkada-2020-di-13-daerahmulai?page $=$ all, diakses tanggal 15 Desember 2020, pukul 17.15 WIB 
https://regional.kompas.com/read/2020/07 /17/17420161/gibran-rekomendasiini-bagi-saya-suatu-kehormatan, diakses tanggal 19 November 2020, pukul 12.20 WIB

\section{Peraturan Perundang-Undangan}

Undang-Undang Dasar Negara Republik Indonesia Tahun 1945.

Undang-Undang Republik Indonesia Nomor 10 Tahun 2016 Tentang Perubahan Kedua Atas undangundang nomor 1 tahun 2015 Tentang Penetapan Peraturan Pemerintah Pengganti UndangUndang Nomor 1 Tahun 2014 Tentang Pemilihan Gubernur, Bupati, dan Walikota Menjadi Undang-Undang.

Undang-Undang Republik Indonesia Nomor 5 Tahun 2014 Tentang Aparatur Sipil Negara (Lembaran Negara Republik Indonesia Tahun 2014 Nomor 6) 